\title{
The Moderating Effects Of E-Government On The Relationship Between Administrative Decentralization And Service Delivery In County Governments In Kenya
}

\author{
Duncan M. Wagana \\ Dr. Mike A. Iravo \\ Dr. Joyce D. Nzulwa \\ Jomo Kenyatta University of Agriculture and Technology, Kenya \\ Prof. John M. Kihoro \\ The Cooperative University College of Kenya, Kenya
}

doi: 10.19044/esj.2016.v12n17p459URL:http://dx.doi.org/10.19044/esj.2016.v12n17p459

\begin{abstract}
This study sought to explore the relationship between the devolved governance aspect of administrative decentralization and service delivery in county governments in Kenya. The study also tested the moderating role of e-government on the relationship between administrative decentralization and service delivery in county governments in Kenya. The study used a sample size of 275 respondents, who are government officials drawn from 8 county governments in Kenya. The study used bivariate regression analysis and moderated multiple regression (MMR) to analyze the association between administrative decentralization, e-government, and service delivery variables. Based on the findings, a significant positive relationship between administrative decentralization and service delivery was established. However, the study found the moderating effect of e-government on the relationship between administrative decentralization and service delivery in county governments in Kenya to be insignificant. Finally, the study drew its conclusion and provided recommendations for future researchers.
\end{abstract}

Keywords: Decentralization, E-Government, Devolution, Administrative, Service delivery

\section{INTRODUCTION}

Decentralization is widely lauded as the key component of good governance and economic development around the world. In the recent past, decentralization policies have been implemented on a large scale throughout 
the developing world (Mitchell \& Bossert, 2010). These have included combinations of political decentralization, which seek to provide citizens and locally elected representatives with greater policy-making power. Fiscal decentralization equips local jurisdictions with greater authority over collection and/or use of revenues spent at the local level. Administrative decentralization is said to expand the local-level's role in delivering public services (Cheema \& Rondinelli, 2007; Mitchell \& Bossert, 2010). Administrative decentralization also seeks to redistribute authority, responsibility, and financial resources for providing public services among different levels of government (Falleti, 2005). It is the transfer of responsibility for the planning, financing, and management of certain public functions from the central government and its agencies to field units of government agencies, subordinate units or levels of government, semiautonomous public authorities or corporations, or area-wide, regional, or functional authorities (Alemu, 2015). Administrative decentralization is also multi-faceted in nature in that it refers to the different aspects of local decision-making power that enables the delivering of services. They include: personnel management, ownership and management of service facilities, management of other material resources in the sector, and administrative discretion over day-to-day operations (Saavedra, 2010).

However, there are various forms of decentralization, including deconcentration, delegation, and devolution. While deconcentration involves the central government re-distributing some decision making authority from the central offices to the field offices of national ministries, delegation entails the transfer of responsibility for certain public functions to sub-national governments. By contrast, devolution requires not only the transfer of responsibility, but also authority over decision-making and accountability to autonomous and legally constituted sub-national governments (Cheema \& Rondinelli, 2007; Olatona \& Olomola, 2015; Resnick, 2014). In a devolved system, local governments have clear and legally recognized geographical boundaries over which they exercise authority and within which they perform public functions (Alemu, 2015). From the global perspective, over seventy five countries have attempted to decentralize responsibilities to lower tiers of government in the last quarter century (Ahmad et al., 2005). In Africa, many central governments have initiated or intensified processes to transfer authority, power, responsibilities, and resources to sub-national levels. The African countries that have decentralized governments include Kenya, Botswana, Burkina Faso, Ethiopia, Ghana, Mali, Mozambique, Nigeria, South Africa, Tanzania, and Uganda (Dickovick \& Riedl, 2010).

In Kenya, devolution is an ambitious form of decentralization involving large-scale political, fiscal, and administrative decentralization (Kenya School of Government, 2015). Unlike other countries where the 
devolution process of the three powers has been sequentially attained, in Kenya, the experience has been a 'big bang.' Here, the three types of decentralization were achieved at once with the ratification of the constitution (Kobia \& Bagaka, 2014). Devolution in Kenya is based on the supremacy of the constitution, sovereignty of the people, and the principle of public participation (ICJ Kenya, 2013). All in all, most countries have decentralized governments with a mix of objectives such as to deliver better public services; to enhance public management, governance and accountability; to bolster economic development; to improve equity in service delivery and development outcomes; and/or to promote a more stable and peaceful state, among others (Smoke, 2015).

\section{PROBLEM STATEMENT}

Researchers have generally supported the position that devolved governance influences service delivery. Empirical evidence supports the existence of a relationship between decentralization and service delivery (Ahmad , Brosio, \& Tanzi, 2008; Besley, Pande, \& Rao, 2007; Freinkman \& Plekhanov, 2009; Kannan, 2013). However, these studies focus mostly on developed or developing countries of Asia and Latin America. The link between devolved governance (administrative decentralization) and public service delivery in the context of Sub-Saharan Africa is scarcely explored. To date, only few studies have so far evaluated the impact of decentralization on service delivery in the context of Sub-Saharan Africa (Balunywa et al., 2014; Tshukudu, 2014). The few studies done locally (Abdumlingo \& Mwirigi, 2014; Kobia \& Bagaka, 2014) are limited. Thus, they suffer from conceptual gaps since they only address the merits and demerits of devolved governance. The study by Simiyu et al. (2014) also faced methodological issues since it was a case study and an explored specific contextual areas (Kimilili constituency development fund). It is due to these conceptual, methodological, and contextual gaps that this study investigated the effects of administrative decentralization on service delivery in county governments in Kenya.

Additionally, most developing countries across the world have adopted e-government as an innovative strategy towards economic reform to add value to economic efficiency and provide a transparent environment to both the government and the public (AL-azar, 2012). According to Alaaraj and Ibrahim (2014), e-government influences service delivery, thus depicting it as a viable moderator in the relationship between administrative decentralization and service delivery. However, research on the moderating effects of e-government on the relationship between administrative decentralization and service delivery is nascent. It is against this backdrop that this study sought to examine the potential moderating role of e- 
government on the relationship between the governance aspect of administrative decentralization and service delivery in Kenya.

\section{OBJECTIVES AND HYPOTHESES OF STUDY}

The general objective of the study was to establish the effect of devolved governance on service delivery as moderated by e-government in county governments in Kenya. Specifically, the study sought to evaluate the effects of administrative decentralization on service delivery in county governments in Kenya. It also sought to find out the moderating effect of egovernment on the relationship between administrative decentralization and service delivery. In order to address the above objectives, the following null hypotheses were tested.

H01: Administrative decentralization is not related to service delivery in county governments in Kenya.

H02: There is no moderating effect of e-government on the relationship between administrative decentralization and service delivery in county governments in Kenya.

\section{THEORETICAL FRAMEWORK}

The study was founded on the theoretical underpinnings of the New Public Management theory.

\section{New Public Management Theory}

The theory of new public management emerged in the 1980s and 1990s. Therefore, it was proposed by Hood (1991) who argued for the reconfiguring of the state along more cost-efficient (and effective) lines. The protagonist recommended that the public sector should be opened up to greater private sector influence. Mongkol (2011), citing Balk (1996) and Hughes (2003), avers that new public management reforms were aimed at improving the quality of public services, saving public expenditure, increasing the efficiency of governmental operations, and making policy implementation more effective. The belief that large and monopolistic public bureaucracies are inherently inefficient was a critical force driving the emergence of the new public management (Andrews, 2012). The theory represents a set of ideas, values, and practices aimed at emulating private sector practices in the public sector (Bourgon, 2007). Recently, Gumede and Dipholo (2014), citing Obsorne and Gaebler (1992), further opined that there was a need to reinvent the government and harness the entrepreneurial spirit to transform the public sector and later "banish the bureaucracy." Bourgon (2007) posits that the new public management theory takes its intellectual foundations from public choice theory, which looks at the government from the standpoint of markets and productivity and from managerialism, which 
focuses on management approaches to achieve productivity gains. The three underlying issues which new public management theory attempts to resolve include: citizen-centered services; value for taxpayers' money; and a responsive public service workforce (Bourgon, 2007).

Notably, there are also studies that indicate that the new public management reforms do not necessarily lead to improved service delivery. For example, Simonet (2008) analyzed governments’ attempts at providing better health-care services for less in Germany, the United Kingdom, Switzerland, France, and Italy. The study concluded that new public management led to greater inequity and more bureaucracy in some countries, but not all. Competition, a major characteristic of the theory, did not necessarily lead to better health outcomes. Furthermore, unlike other sectors, the application of new public management theory in health care meant larger providers (insurers, hospitals) and the regulations remain strong. The new public management is often mentioned together with governance (Tolofari, 2005). Governance is about the overarching structure of government and the setting up of overall strategy, while new public management is the operational aspect of the new type of public administration. The theory has also received support from Zungura (2014) who contends that the dominant theme of new public management is the use of market techniques to improve the performance of the public sector. Subsequently, the main features of new public management include performance management, e-governance, contracting out and outsourcing, decentralization and accountability, among others (Zungura, 2014).

The new public management theory has also been criticized due to several short comings. First, Mongkol (2011), citing Kaboolian (1998) and Khademian (1998), pointed out that the theory introduces a paradox of centralization through decentralization. Giving public managers more authority to manage programs may result in concentrated decision making. Thus, new public management may lead to centralized decision making by public managers, rather than encouraging decentralization in public organizations as it claims. The second criticism concerns applying private sector management techniques to the public sector. While new public management has encouraged the use of private sector management techniques, there may be risks associated with adopting some private sector practices. Many academic commentators argued that most areas of public service and administration have distinct political, ethical, constitutional and social dimensions, and these factors make the public sector different from the private sector (Mongkol (2011) [citing Armstrong (1998) and Flynn (2002)]). Lastly, the new public management theory is based on applying market principles to public policy and management. However, Mongkol (2011), quoting Hughes (2003), argued that the governments of developing 
countries often have only little experience in the operation of markets. Basic infrastructure of management in developing countries is also not sufficient to support market-oriented reforms (Barker, 2006). Moreover, there are various factors which are required before the market can be effective. Mongkol (2011), quoting Hughes (2003), pointed out that markets are ineffective without the rule of law, for example, to ensure compliance with contracts.

The theory is important in understanding service delivery variable. The rationale of establishing county governments is to ensure efficient service delivery. In this regard, county governments are important tools for new public management reforms in improving the quality of public services and increasing the efficiency of governmental operations. The new public management theory is, therefore, evident in the quality of services delivered by the county governments. In addition, the new public management theory provides a foundation for predicting the link between administrative decentralization, e- government, and service delivery. The moderating variable (e-government) was examined based on new public management theory as emerging governance dynamic. E-government is seen as a product of the reforms being advanced by the new public management theory. In addition, it is an output-oriented and a demand-driven approach that gives premium to providing high quality services to citizens. Cordella (2007) argued that e-government is seen as a next step in the rationalization of government activities. Literature review points to four e-government developmental stages from a user-centric perspective. The four stages include: one-way information flows, two-way interaction, payment transaction, and e-democracy (Chatfield \& Alhujran, 2007). Therefore, this study examined whether e-government moderates the relationship between decentralization and service delivery as drawn from the foundations of the new public management theory.

\section{EMPIRICAL LITERATURE REVIEW}

This paper discusses previous empirical literature on the relationship between administrative decentralization and service delivery. The paper also reviews empirical work on the relationship between e-government and service delivery.

\section{Administrative Decentralization and Service Delivery}

Administrative decentralization is concerned with the functional tasks of decentralization (Stanton, 2009). It relates to the assignment of service delivery powers, functions across levels of government, and determines where responsibility is situated. Furthermore, it involves the transfer of civil servants and public functions to the lower level of government (Olatona \& Olomola, 2015). Administrative decentralization is the full or partial transfer 
of functional responsibilities to the sub-national units of governance. The national government assigns local governments the authority to hire and fire local staff without prior approval of the central government (Stanton, 2009). Administrative decentralization seeks to redistribute authority, responsibility, and financial resources for providing public services between different levels of government. Therefore, the responsibility for planning, financing, and managing certain public functions is transferred from the central government to subordinate levels of government, semi-autonomous public authorities or corporations, or area-wide, regional, or functional authorities (Ozmen, 2014).

Akorsu (2015), citing Falleti (2004), argued that administrative decentralization has either a positive or negative impact on the autonomy of sub-national executives. If administrative decentralization improves local and state bureaucracies, fosters training of local officials or facilitates learning through the practice of delivering new responsibilities, it will likely increase the organizational capacities of sub-national governments. Nevertheless, if administrative decentralization takes place without the transfer of funds, this reform may decrease the autonomy of sub-national officials. Hence, these officials will be more dependent on subsequent national fiscal transfers or sub-national debt for the delivery of public services (Akorsu, 2015). In a study in the United States, Saavedra (2010) examined the effects of administrative decentralization on access to two key services: health care and improved drinking water sources. The study provided evidence supporting positive and significant effects of administrative decentralization on access to health care and improved water provision. In another study, Mobarak, Rajkumar and Cropper (2006), using data from Brazilian municipalities, found that administrative decentralization only provides good results when it is accompanied by good governance. A study in South Africa by Stanton (2009) explored the extent of the problems of providing basic services that are experienced by municipalities and influenced by the administrative configuration of the decentralized system of governance. The study concluded that local councils had the authority to pass by-laws with respect to the implementation of their legally assigned functions and responsibilities. However, municipalities had limited autonomy and needed provincial approval when contracting out responsibilities and services.

In a related study, Bogopane (2014) explored the impact of perceived erosion of the politics-administration dichotomy on good governance and service delivery. The study concluded that strong visionary, political and administrative leadership, vibrant apolitical and strong public bureaucracy, and integrated political and administrative structures lead to the improvement of the functionality and performance of politics-administration dichotomy relations. In Ghana, Alornyeku (2011) carried a case study in 
Kumasi metropolis on administrative structure and service delivery. The study revealed that even though there was a clear practice of division of labour, there were departments’ lack of technical equipment. This, however, resulted to delays in meeting the expectation of citizens. In addition, assembly low productivity, due to excessive bureaucracy, has negatively impacted the performance of the central government. For Nigeria, Boris (2015) carried an empirical study to examine the challenges confronting local government administration in effective and efficient social service delivery at the grassroots. Using secondary data, the study concluded that lack of funds, corruption, and undue political interference amongst others was the major constraints to local government service delivery. Overall, there is a relatively small body of work that has attempted to systematically examine the evidence on the impact of administrative decentralization on service delivery in developing countries. However, the ongoing researches have paid inordinate attention to the impact of administrative decentralization on service delivery.

\section{E-Government and Service Delivery}

Electronic government, popularly referred to as e-government, can be broadly defined as the use of information and communication technologies (ICTs) by governments to operate more effectively and transparently; to provide more and better information and services to the public; and to facilitate the participation of individuals, businesses, and groups throughout society in their own governance (Curtin, 2007). E-government entails the use of information and communication technology as the new way forward in public administration (Chatfield \& Alhujran, 2009; Jeong, 2007). Notably, most developing countries are adopting e-government as an innovative strategy in their economic reform since it adds value to the economic efficiency and provides a transparent environment to both the government and the public (AL-azar, 2012). It has been argued that e-government initiatives such as e-service, e-administration, and e-procurement eradicates corruption and improves service delivery in public sector (Bwalya, 2012). According to Srivastava (2011), e-government research is classified into three broad areas: the evolution and development of e-government initiatives, adoption and implementation perspectives, and the impact of egovernment on stakeholders

Over the last few years, researchers have examined the link between e-government and service delivery. Majority of the prior research have focused on the direct relationship between e-government and service delivery. For example, Singh et al. (2010) carried out an empirical work in Fiji and Papua, New Guinea. Thus, they established that e-governance has the potential to improve public service delivery. The finding suggested that 
e-governance contributes to effectiveness, efficiency, and equity in public services that enhances the quality of public service delivery. In the context of Bangladesh, Bhuiyan (2011) found that e-governance played a significant role in the modernization of public administration for efficient and effective service delivery to the citizens of Bangladesh, as well as its potential to combat corruption and reduce poverty. For Spain, García-Sánchez et al. (2013) analyzed the development of e-government in 102 Spanish municipalities, both as an overall process and in each of the three stages (egovernment, e-governance, and e-democracy). However, they revealed that the Spanish legislation needs to regulate the development of local government e-administration in order to improve the current one-way eparticipatory status towards a two-way relationship of mutual feedback and finally to a partnership relationship between government and society.

Elsewhere, Kazakhstan by Bhuiyan (2011) carried out a study and reported that even with partial implementation, e-government accrues benefits. Also, they reported that operational challenges, such as the lack of political support and consensus, the digital divide, the lack of qualified human resources, language and infrastructure development, needs to be addressed to ensure a cost-efficient, cost-effective, accountable, and transparent service delivery to Kazakhstanis. Another study in India by Monga (2008) demonstrated that e-governance brought about a revolution in the quality of service delivery to the citizens. This was achieved by improving transparency in the administrative process, saving time due to single window service provisions, simplifying procedures, reducing corruption, improving office and record management, and improving the attitude and behavior of civil servants.

In United States, Pan \& Jang (2008) investigated the effects on the evolvement of e-government online service delivery in U.S. Cities. The researchers found that city population, council-manager form of government, and the presence of e-government development plans are positively related to service advancement. Similarly, using publicly available data from 178 countries, Krishnan \& Teo (2012) tested the moderating effects of governance on information infrastructure and e-government development. The study revealed that political stability, government effectiveness, and the rule of law moderated the relationship of information infrastructure with egovernment development in a positive direction. On the other hand, voice and accountability, and control of corruption moderated the relationship negatively. Elsewhere, Chatfield and Alhujran (2009) examined egovernment websites and portals of 16 Arab countries to assess their development stages in e-government service delivery capability. The researchers compared Arab e-government developments with selected developed countries (United States, Denmark, Sweden, UK, South Korea, 
and Australia). The study found evidence that most Arab countries are in the first stage of e-government development; namely: one-way information flow from the government online to the public. The study also revealed a wide digital divide that remains between the Arab countries and the leading developed countries.

For Nigeria, Asogwa (2013) using a sample of ten federal government ministries, revealed that e-government provides faster access to government information, lowers administrative costs, increases transparency in government ministries, and reduces bribery and corruption, among others. In addition, these opportunities were threatened by low bandwidth and internet penetration, inadequate ICT infrastructure and technicians, incessant power outages, technological obsolescence, and other barriers in Nigeria. Another study by Alaaraj and Ibrahim (2014) found that e-government development has a positive and significant influence on good governance. Particularly, good governance is positively and significantly influenced by eservice, but not by e-administration and e-procurement. Additionally, Naz (2009) carried out a study in Fiji to examine the role of e-governance in improving service delivery and quality, and the impact it has on customer satisfaction. The study concluded that e-governance has the potential to improve service delivery and customer satisfaction. All in all, previous egovernment research focuses on developed countries (Kim, 2009; Krishnan \& Teo, 2012; Pan \& Jang, 2008). Consequently, little is known about the current state of e-government in developing countries and its impact on service delivery. In addition, evidence is still lacking on the moderating role of e-government development on the relationship between decentralization and public service delivery in developing countries.

\section{RESEARCH METHODOLOGY}

This study used descriptive survey research design and explanatory research design to help identify, analyze, and describe the relationship between devolved governance and public service delivery in county governments in Kenya. Descriptive survey research studies are those studies which are concerned with describing the characteristics of a particular individual or of a group. However, diagnostic research studies determine the frequency with which something occurs or its association with something else (Kothari, 2004). In contrast, explanatory research design describes, in quantitative terms, the degree to which variables are related (Mugenda \& Mugenda, 2003). It is used in studies that are aimed at establishing causal relationships between variables (Bryman \& Bell, 2007; Cooper \& Schindler, 2006). In this study, the target population was the total number of county government officials in all the 47 counties in Kenya. The target population was 2,794 county government officials from all the 47 counties in Kenya. 
The list of the 2,794 county government officials was sourced from the directory of the Commission on Revenue Allocation (2011). The county government officials comprised of 485 county ministers and secretaries, 1573 MCAs, 291 sub county administrators, and 445 county directors/chief officers. The distribution of county government officials across the country is relatively not homogeneous in terms of population and geographical location in all the 47 Counties in Kenya. In this study, the population was large and stratified. Therefore, to get the sample size for the proportions, the study used the formula provided by Kothari \& Garg (2014) to yield a sample size of 275 county government officials. Generally, sample sizes larger than 30 and less than 500 are recommended for statistical data analysis (Churchill \& Brown, 2004; Mugenda \& Mugenda, 2003).

The data collected was analyzed using descriptive statistics such as mode, median, mean, and standard deviation. Inferential statistics such as multiple regression modeling were employed to study the causal relationships among all the variables in the model. According to Mugenda and Mugenda (2003), multiple regression analysis attempts to determine whether a group of variables together predict a given dependent variable, and in this way attempts to increase the accuracy of the estimate. The use of multiple regression model is preferred due to its ability to show whether there is a positive or a negative relationship between independent and dependent variables (Mason, Lind, \& Marchal, 1999). In addition, the study used bivariate regression analysis and moderated multiple regression to analyze the association between independent, moderating, and dependent variables.

\section{EMPIRICAL FINDINGS}

The gathered data was analyzed through IBM SPSS for data description and hypotheses testing.

\section{Descriptive Statistics}

Table 1 shows the descriptive statistics of the independent, moderating, and dependent variables. The descriptive statistics include mean, standard deviation, minimum, and maximum which were computed using SPSS version 21.

Table 1. Descriptive Statistics of Aggregated Variables

\begin{tabular}{ccccc}
\hline & Minimum & Maximum & Mean & $\begin{array}{c}\text { Std. } \\
\text { Deviation }\end{array}$ \\
\hline Administrative Decentralization & 1.38 & 5.00 & 4.03 & 0.64915 \\
E-Government & 1.00 & 5.00 & 3.36 & 0.72174 \\
Service Delivery & 1.00 & 5.00 & 3.80 & 0.60872 \\
\hline
\end{tabular}


Table 1 shows that administrative decentralization had the highest mean of 4.03. This indicates that majority of the respondents agreed with the items, meaning that administrative decentralization existed and was mostly practiced in county governments in Kenya. Administrative decentralization could be the most exercised form of decentralization in county governments in Kenya. The standard deviation for administrative decentralization was 0.64915. This standard deviation is low, meaning that there were no extremes in the positive and negative in the scoring. The mean for service delivery was 3.80. This implies that majority of the respondents also agreed with service delivery items, meaning it is frequently practiced in county government in Kenya. The standard deviation for service delivery was 0.60872. The standard deviations are low, implying that the respondents generally agreed in the scoring of service delivery items. It can therefore be said that there were no extremes in the scoring. Hence, it is a good measure. Furthermore, majority of the respondents also agreed about e-government as the variables had a mean of 3.36. As such, it could be said that county governments have embraced e-government. The standard deviation for service delivery was 0.72174 respectively. The standard deviations are low, implying that the respondents generally agreed in the scoring of egovernment items. It can therefore be said that there were no extremes in the scoring. Hence, it is a good measure.

\section{Correlation Analysis}

A correlation analysis was computed, examined, and interpreted. Correlation analysis is useful in describing the strength and direction of the linear relationship between two variables (Pallant, 2011). Mugenda and Mugenda (2003) posit that correlation coefficient tells the magnitude of the relationship between two variables. If the correlation coefficient is positive $(+)$, it means that there is a positive relationship between the two variables. A negative relationship (-) means that as one variable decreases, then the other variable increases. Thus, this is termed as an inverse relationship. A zero value of $\mathrm{r}$ indicates that there is no association between the two variables. The results of correlation analysis are summarized in table 2 below:

Table 2. Correlation Matrix of the Study Variables

\begin{tabular}{ccccc}
\hline \multicolumn{2}{c}{ Variable } & $\begin{array}{c}\text { Service } \\
\text { Delivery }\end{array}$ & $\begin{array}{c}\text { Administrative } \\
\text { Decentralization }\end{array}$ & E-Government \\
\hline Service Delivery & Pearson Correlation & 1 & \\
& Sig. (2-tailed) & & \\
Administrative & Pearson Correlation & $0.382^{* *}$ & 1 & \\
Decentralization & Sig. (2-tailed) & 0.000 & & 1 \\
E-Government & Pearson Correlation & $0.373^{* *}$ & $0.263^{* *}$ & \\
& Sig. (2-tailed) & 0.000 & 0.000 & 275 \\
\hline & $\mathrm{N}$ & 275 & 275 &
\end{tabular}


The results in table 2 revealed that administrative decentralization positively and significantly correlated with service delivery significant at 0.001 level of significance. The correlation coefficient as indicated in table 2 was $\mathrm{r}=0.382$, $\mathrm{p}$-value $<0.001$. The correlation coefficient between service delivery and moderating variable (e-government) was positive and significant $(\mathrm{r}=0.373, \mathrm{p}$-value $<0.001)$. In addition, the correlation coefficient between independent variable (administrative decentralization) and moderating variable (e-government) was also positive and significant $(\mathrm{r}=0.263$, $\mathrm{p}$-value $<0.001)$.

\section{Regression Analysis}

Regressionanalysiswasconductedtoempirically determinewhetheradministrative decentralization wasasignificantdeterminantofservice delivery.The regression model results in table 4.29 indicated that the values of $\mathrm{R}$ and $\mathrm{R}$ squared were 0.382 and 0.146 respectively. This showed that there was a positive relationship between administrative decentralization and service delivery. The R squared was the coefficient of determination which indicated that explanatory power of the independent variable (administrative decentralization) was 0.146. This indicated that $14.6 \%$ of variances in service delivery areexplainedby thevariancesinthe administrative decentralization. It follows that other factors outside the current model explain $85.4 \%$ of variation in service delivery. The correlationcoefficientof0.382indicatesthatthe combined effect of thepredictorvariables haveapositive correlation with service delivery.

Table 3. Regression model for Administrative Decentralization

\begin{tabular}{cccc}
\hline $\mathrm{R}$ & $\mathrm{R}$ Square & Adjusted R Square & $\begin{array}{c}\text { Std. Error of the } \\
\text { Estimate }\end{array}$ \\
\hline 0.382 & 0.146 & 0.143 & 0.56366 \\
\hline
\end{tabular}

Theoverallmodelsignificance waspresentedintable4.The model was found to be valid and significant $(\mathrm{F}(1,273)=46.563$, $\mathrm{p}<0.001)$.

Table 4. ANOVA of Administrative Decentralization and Service delivery

\begin{tabular}{cccccc}
\hline & Sum of Squares & df & Mean Square & F & Sig. \\
\hline Regression & 14.793 & 1 & 14.793 & 46.563 & $.000 \mathrm{~b}$ \\
Residual & 86.734 & 273 & 0.318 & & \\
Total & 101.527 & 274 & & & \\
\hline
\end{tabular}

The study further determined the beta coefficients of administrative decentralization. Table 5 displays the regression coefficients of the independent variable (administrative decentralization). The results reveal that administrative decentralization is statistically significant in explaining the service delivery of county governments in Kenya. However, this is supported by beta $=0.382, \mathrm{p}<0.001$. The results imply that a unit change in 
administrative decentralization will lead to a positive change in service delivery at the rate of 0.358 .

Table 5. Regression Coefficients of Administrative Decentralization

\begin{tabular}{|c|c|c|c|c|c|}
\hline & \multicolumn{2}{|c|}{$\begin{array}{l}\text { Unstandardized } \\
\text { Coefficients }\end{array}$} & \multirow{2}{*}{$\begin{array}{l}\text { Standardized } \\
\text { Coefficients } \\
\text { Beta }\end{array}$} & \multirow[t]{2}{*}{$\mathbf{T}$} & \multirow[t]{2}{*}{ Sig. } \\
\hline & B & $\begin{array}{l}\text { Std. } \\
\text { Error }\end{array}$ & & & \\
\hline (Constant) & 2.358 & 0.214 & & 11.007 & 0.000 \\
\hline $\begin{array}{l}\text { Administrative } \\
\text { Decentralization }\end{array}$ & 0.358 & 0.052 & 0.382 & 6.824 & 0.000 \\
\hline
\end{tabular}

The model indicates that administrative decentralization is statistically significant in explaining the variation in dependent variable (service delivery). The reported probability of 0.000 is less than the probability of 0.001 . On substitution of the coefficients in the equation below, we obtain:

Service Delivery $=2.358+0.358$ administrative decentralization

Using results in table 5, the study rejected hypothesis H01: there is no relationship between administrative decentralization and service delivery in county governments in Kenya. Therefore, the study concluded that administrative decentralization had a positive and significant influence on service delivery in county governments in Kenya. The high residual sum of squares (86.734) indicates that the model does not explain all the variations in service delivery. Also, there are other factors outside the model that account for a higher proportion of the variation in service delivery. The findings are consistent with Kosec and Mogues (2015) who analyzed the impact of administrative district level decentralization on agricultural and rural service delivery. The study found that administrative decentralization has led to increased access to agricultural extension services and to the greater use of modern agricultural inputs, such as fertilizer and improved seed. In another study in the United States, Saavedra (2010) examined the effects of administrative decentralization on access to two key services: health care and improved drinking water sources. The study provided evidence supporting positive and significant effects of administrative decentralization on access to health care and improved water provision. In another study, Mobarak, Rajkumar and Cropper (2006) using data from Brazilian municipalities, found that administrative decentralization only provides good results when it is accompanied by good governance. A study in South Africa by Stanton (2009) explored that the extent of the problems of providing basic services currently experienced by municipalities are influenced by the administrative configuration of the decentralized system of governance. Therefore, the study concluded that local councils had the 
authority to pass by-laws with respect to the implementation of their legally assigned functions and responsibilities.

\section{Moderated Multiple Regression (MMR) Analysis}

To test the moderating role of e-government on administrative decentralization and service delivery, moderated multiple regression (MMR) was used. A moderator variable influences the relationship between the dependent variable and the independent variable. The direction and magnitude of the relationship depends on the value of the moderator (Sekaran, 2006). This study identified e-government as a moderator variable affecting the relationship between administrative decentralization (independent variable) and service delivery (dependent variable) in county governments in Kenya. The study performed regression analysis to test the moderating effect of e-government on the relationship between administrative decentralization and service delivery in county governments in Kenya. Using moderated multiple regression (MMR) analysis in this study, the moderating effect of the variable (interaction term) was analyzed by interpreting the $\mathrm{R}^{2}$ change in the models obtained from the model summaries and by interpreting the regression coefficients for the interaction term obtained from the coefficients tables.

Table 6 shows the moderating effect of e-government on the relationship between administrative decentralization and service delivery.From table 6,Model 1 shows that $\mathrm{R}=0.475, \mathrm{R}^{2}=0.226$ [F (2, $272)=39.627 \mathrm{p}=0.000<0.001]$. The value of $\mathrm{R}^{2}$ indicates that $22.6 \%$ of thevariance in the service delivery can be accounted for by e-government scores and administrative decentralization.The interaction terms between administrative decentralization and e-government were examined to test the moderating effects in this study. Model 2 in table 6 shows the results after the interaction term (administrative decentralization*e-government) was added into the model. The results indicated that the inclusion of the interaction term resulted into an increase in $\mathrm{R}^{2}$ by $0.7 \%[\mathrm{~F}(1,171)=2.449$, $\mathrm{p}=0.119]$. Model 2 in table 6 was reported to be significant at the 0.001 level of significance. However, this model was found to be insignificant $\left(\mathrm{R}^{2}\right.$ change $=0.007, p=0.119>0.001$ ) showing no presence of moderating effect . To put it differently, the moderating effect of e-government failed to contribute variance in the service delivery, above and beyond the variance by e-government and administrative decentralization. 
Table 6. Moderated Multiple Regression Model Summary for Administrative Decentralization

\begin{tabular}{|c|c|c|c|c|c|c|c|c|c|}
\hline \multirow[t]{2}{*}{ Model } & \multirow[t]{2}{*}{$\mathbf{R}$} & \multirow{2}{*}{$\begin{array}{c}\mathbf{R} \\
\text { Square }\end{array}$} & \multirow{2}{*}{$\begin{array}{c}\text { Adjusted } \\
\text { R } \\
\text { Square }\end{array}$} & \multirow{2}{*}{$\begin{array}{c}\text { Std. } \\
\text { Error of } \\
\text { the } \\
\text { Estimate }\end{array}$} & \multicolumn{5}{|c|}{ Change Statistics } \\
\hline & & & & & $\begin{array}{c}\mathbf{R} \\
\text { Square } \\
\text { Change }\end{array}$ & $\begin{array}{c}\text { F } \\
\text { Change }\end{array}$ & df1 & df2 & $\begin{array}{c}\text { Sig. F } \\
\text { Change }\end{array}$ \\
\hline 1 & $0.475 a$ & 0.226 & 0.220 & 0.53763 & 0.226 & 39.627 & 2 & $272 a$ & 0.000 \\
\hline 2 & $0.482 b$ & 0.233 & 0.224 & 0.53620 & 0.007 & 2.449 & 1 & $271 b$ & 0.119 \\
\hline
\end{tabular}

a. Predictors: (Constant), e-government level, administrative decentralization

b. Predictors: (Constant), e-government level, administrative decentralization, administrative decentralization*e-government.

Intable7,Model1 in dicates that administrative decentralization was statistically significant $(\mathrm{p}=0.000<0.001$; Betavalue $=0.304)$.E-government was also statistically significant $(\mathrm{p}=0.000<0.001$; Betavalue $=0.293)$.The results revealed that for a 1-unit increase in administrative decentralization,the service delivery is predicted to have adifference of 0.286 , given that the e-government is held constant. The regression coefficient associated with e-government means that the difference in service delivery between counties with high e-government and counties with low egovernment is 0.247,given that administrative decentralizationis held constant. On substitution of the coefficientsinequation 6 below, weobtained:

\section{Service Delivery $=3.802+0.286$ Administrative Decentralization +0.247}

\section{E-government}

Intable7,Model2 reveals the details of the inclusion of the interactive term int he model.Administrative decentralization was found to be significant $(p<0.001$,Betavalue=0.287). E-government was found to be significant $(p<0.001$,Betavalue $=0.288)$, and administrative decentralization *egovernment was found to be insignificant $(p=0.119>0.001$, Beta value $=-$ 0.085).The result for table 7 in dicates that for a1-point increase in the a dministrative decentralization,theservice delivery is predicted to have adifference of 0.270 ,giving that e-government is held constant. Furthermore, for a 1-point increase in e-government,the service delivery is predicted to have adifference of 0.243 ,giving that administrative decentralization is held constant. The interpretation of the regression coefficient for the interaction term in equation below isthattherewasa -0.090 differencebetweenthe slopeof service deliveryonadministrative decentralization between counties with low e-government andthose with high e-government. However,the slope regressing service delivery on administrative decentralization is steeper for counties with high e-government as compared to counties with low egovernment. 
Table 7. Moderated Multiple Regression Model Coefficients

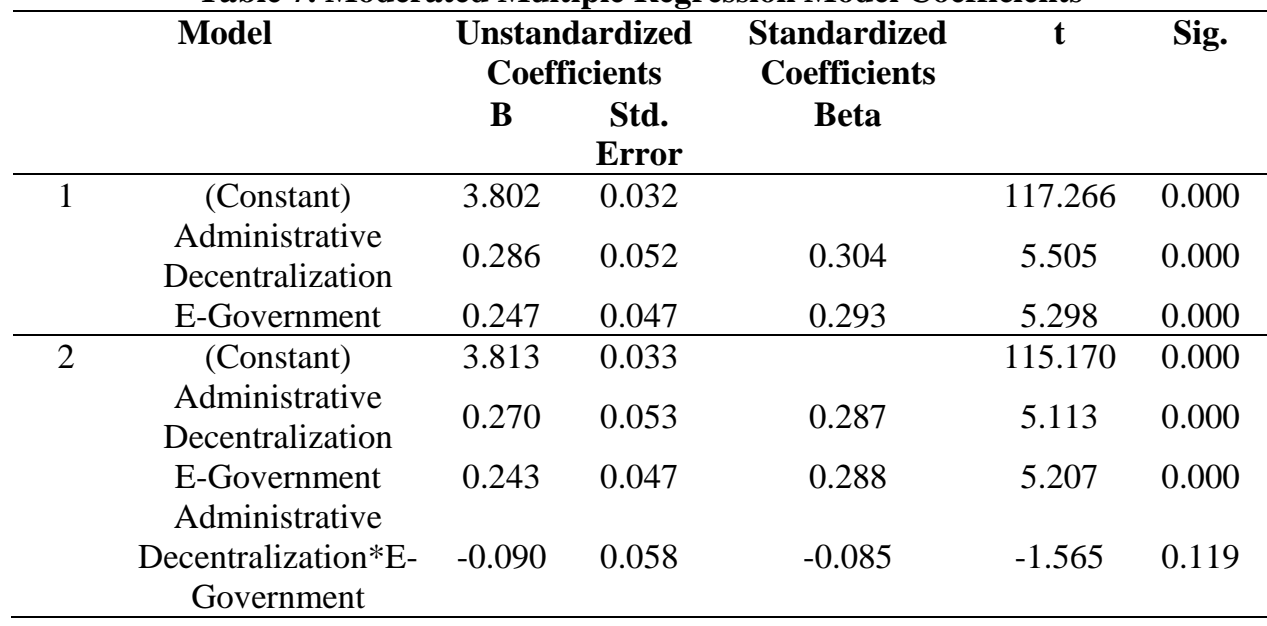

Using the results in table 7, the hypothesis below was tested:

H02: There is no moderating effect of e-government on the relationship between administrative decentralization and service delivery in county governments in Kenya. The study found that there was no significant interaction between the effects of e-government and administrative decentralization ( $\mathrm{p}=0.119>0.001$ ). Consequently, the study failed to reject the null hypothesis that there is no moderating effect of e-government on the relationship between administrative decentralization and service delivery in county governments in Kenya. The results revealed that e-government does not moderate the relationship between administrative decentralization and service delivery.

\section{CONCLUSION AND RECOMMEDATIONS}

The study concluded that there exists a significant positive relationship between administrative decentralization and service delivery in county governments in Kenya. Administrative decentralization practices were found to influence service delivery in county governments in Kenya. However, it was concluded that e-government had no significant moderating effect on the relationship between administrative decentralization and service delivery in county governments in Kenya. Ultimately,thisstudy,like prior studies,offerssomerecommendations. First,this study recommends future researchers to replicate the same research in other African countries. Second,this studys uggests future authors to investigate others variables besides the variables already investigated. These include: voice and accountability, political stability, government effectiveness, regulatory quality, rule of law, control of corruption and others, which facilitate enhancement of service delivery in devolved governments. In addition, it also provide a clear picture of all governance mechanisms that may help 
policy makers to improve devolution .Third,this study is among the pioneering study to explore the moderating effect of e-government on the relationship between administrative decentralization and service delivery. So,it recommends future studies to test moderating role of variables such as experience, qualification,age,religion,sex and others on the relationship between administrative decentralization and service delivery. Fourth ,the present study further recommends future researchers toexamine this relationship through moderator and mediator variables.Fifth, the few previous studies on this issue examined the link between administrative decentralization, e-government, and service delivery based on data from a single country. While this approach has the advantage of presenting a more focused and detailed view, it does not help to provide international comparisons and cross-country empirical evidence. Hence, this studysuggests that future authorsextendthe samplingtoother countriesand the duration of studyfromfive years to enable international comparisons and cross-country empirical evidence.

\section{IMPLICATIONS OF THE RESEARCH}

The practical implication of this research is that it will inform government policy on the devolution and service delivery. By illustrating the effect of devolved governance on service delivery in county governments in Kenya, policy makers may use the finding of this study to better, align or revise the existing legal framework, policies and the guidelines of devolution process. Further, the findings may influence the governments to develop appropriate policies to enhance devolution processes so as to improve service delivery to the public. To the scholars, this research will add value to the existing body of knowledge as it develops comprehensive model on devolved governance in Kenya and beyond. The research will thus benefit the scholars wishing to undertake further studies aimed at improving devolved governance structures in local and global context. Nevertheless, this research serves as a stepping stone for further research on devolution and service delivery.

\section{References:}

Abdumlingo, H., \&Mwirigi, M. F. (2014). Challenges of managing devolved funds in the delivery of services: A case study of Mombasa county. International journal of research in commerce \& management, 5(5), 1-4.

Ahmad, Junaid, Devarajan, S., Khemani, S., \&Shah, S. (2005). Decentralization and Service Delivery. Policy Research Working Paper 3603. . The World Bank: Washington, D.C.

Ahmad , E., Brosio, G., \&Tanzi, V. (2008). Local service provision in selected OECD countries: Do decentralized operations work better? . Working Paper, No. 08/67. Washington, D.C: International Monetary Fund. 
Akorsu, P. K. (2015). An evaluation of the effectiveness of revenue mobilisation in the public sector of Ghana the case of cape coast metropolitan assembly. International Journal of Economics, Commerce and Management, 3(1), 1-16.

AL-azar (2012). AUB-led workshop: E-government paves the way for better relations between citizens and the state. American University of Beirut: Egovernment stakeholders engagement workshop. Retrieved from http://www.aub.edu.Ib/communications/media/Documents/april-2012/egovernment-EN.pdf.

Alaaraj, H., \&Ibrahim, F. W. (2014). The Influence of E-government Practices on good governance from the perspective of Public in Lebanon. Journal of Public Administration and Governance, 4(3), 171-185.

Alemu, K. T. (2015). District Level Decentralization and Public Service Delivery in Ethiopia: Cases from Amhara region. International Journal of African and Asian Studies, 10.

Alornyeku, F. K. (2011). The Impact Of Bureaucracy On Public Service Delivery: A Study of Kumasi Metropolitan Assembly. (Executive Masters of Public Administration), Kwame Nkrumah University of Science and Technology.

Andrews, R. (2012). New public management and citizens' perceptions of local service efficiency, responsiveness, equity and effectiveness. COCOPS Working Paper No. 7.

Armstrong, A. (1998). A comparative analysis: New public management-the way ahead. Aust. Journal Public Administration, 57, 12-24.

Asogwa, B. E. (2013). Electronic government as a paradigm shift for efficient public services Opportunities and challenges for Nigerian government. Emerald Group Publishing Limited, 31(1), 141-159.

Balk, W. L. (1996). Managerial Reform and Professional Empowerment in the Public Service. Quorum Books, Westport, CT.

Balunywa, W., Nangoli, S., Mugerwa, G. W., Teko, J., \&Mayoka, K. G. (2014). An analysis of fiscal decentralization as a strategy for improving revenue performance in Ugandan Local governments Journal of Research in International Business and Management, 4(2), 28-36.

Barker, A. E. (2006). New public management in developing countries: An analysis of success and failure with particular reference to Singapore and Bangladesh. International . Journal of Public Sector Management., 19, 180203.

Besley, T., Pande, R., \&Rao, V. (2007). Political economy of panchayats in south India. Economic and Political Weekly, 42(8), 661-666.

Bhuiyan H, S. (2011). Trajectories of E-Government Implementation for Public Sector Service Delivery in Kazakhstan. International Journal of Public Administration, 34(9), 604-615. 
Bhuiyan, S. H. (2011). Modernizing Bangladesh public administration through e-governance: Benefits and challenges. . Government Information Quarterly, 28(1), 54-65.

Bogopane, L. (2014). A qualitative exploratory analysis of the impact of perceived erosion of the politicsadministration dichotomy on good governance and service delivery in a democratic developmental state: South african perspective. European Scientific Journal, 211-222.

Boris, O. H. (2015). Challenges Confronting Local Government Administration in Efficient and Effective Social Service Delivery: The Nigerian Experience. International Journal of Public Administration and Management Research, 2(5), 12-22.

Bourgon, J. (2007). Responsive, responsible and respected government:towards a New Public Administration theory. International Review of Administrative Sciences, 73(1), 7-26.

Bryman, A., \&Bell, E. (2007). Business Research Methods. Oxford: Oxford University Press.

Bwalya, K. e. a. (2012). E-government and technological utopianism: exploring Zambia's challenges and opportunities. Electronic Journal of eGovernment, 10(1), 16-30.

Chatfield, A., \&Alhujran, O. (2007). An analysis of e-government maturity models from a user centric perspective: Toward a public value proposition. Proceedings of EEE'07 - The 2007 International Conference on e-Learning, $e$-Business, Enterprise Information Systems, and e-Government, wMonte Carlo Resort, Las Vegas, Nevada, June 25-28, 2007.

Chatfield, A. T., \&Alhujran, O. (2009). A Cross-Country Comparative Analysis of E-Government Service Delivery among Arab Countries. Information Technology for Development, 15(3), 151-170.

Cheema, G. S., \&Rondinelli, D. A. (2007). Decentralizing Governance: Emerging Concepts and Practices. . Cambridge, MA: Ash Institute for Democratic Governance and Innovation, John F. Kennedy School of Government and Washington, DC: The Brookings Institution Press.

Churchill, G. A., \&Brown, T. J. (2004). Basic Marketing Research, Ohio: Thompson Corporation.

Commission on Revenue Allocation. (2011). Kenya County Fact Sheets. Cooper, D. R., \&Schindler, P. S. (2006). Business Research Methods (9th ed. ). New York: McGraw- Hill.

Cordella, A. (2007). E-government: Towards the e-bureaucratic form? , 22,. Journal of Information Technology, 22, 265-274. .

Curtin, G. G. (2007). E-Government. Encyclopedia of Political Communications ,Sage Publications. 
Dickovick, T. J., \&Riedl, R. B. (2010). Comparative Assessment Of Decentralization In Africa: Final Report And Summary Of Findings. United States Agency for International Development.

Falleti , T. G. (2004). A Sequential Theory of Decentralization and Its Effects on the Intergovernmental Balance of Power: Latin American Cases in Comparative Perspective. working paper, 314.

Falleti, T. G. (2005). A sequential theory of decentralisation: Latin American cases in comparative perspective. The American Political Science Review, 99(3), 327-346.

Flynn, N. (2002). Explaining New Public Management: The Importance of Context. In: New Public Management: Current Trends and Future Prospects. McLauglin, K., S.O. Osborne and E. Ferlie (Eds.). Routledge, London.

Freinkman, L., \&Plekhanov, A. (2009). Fiscal decentralisation and the quality of public services in Russian regions. Working Paper No. 111.

García-Sánchez, I.-M., Rodríguez-Domínguez, L., \&Frias-Aceituno, J.-V. (2013). Evolutions in E-governance: Evidence from Spanish Local Governments. Environmental Policy and Governance, 23, 323-340.

Gumede, N., \&Dipholo, K. B. (2014). Governance, Restructuring and the New Public Management Reform: South African Perspectives. Journal of Educational and Social Research, 4(6), 43-50.

Hood, C. (1991). A public management for all seasons? . Public Administration, 69(1), 3-19.

Hughes, O. E. (2003). Public Management and Administration. Palgrave Macmillan, New York.

ICJ Kenya. (2013). Handbook on devolution. The Kenyan Section of the International Commission of Jurists.

Jeong, C. (2007). Fundamental of Development Administration. Selangor: Scholar Press. ISBN 978-967-5-04508-0.

Kaboolian, L. (1998). The new public management: Challenging the boundaries of the management vs. administration debate. . Public Admin. Rev., 58, 189-193.

Kannan, E. (2013). Does Decentralization Improve Agricultural Services Delivery? - Evidence from Karnataka. Agricultural Economics Research Review, 26(2), 99-208.

Kenya School of Government. (2015). Building Public Participation in Kenya's Devolved Government. WORKING PAPER 1 - Overview Note.

Khademian, A. M. (1998). What do we want public managers to be: Comparing reforms. Public Admin. Rev., 58, 269-273.

Kim, S. (2009). A case study of local e-government performance in South Korea: Do leadership and management for results matter? International Public Management Review, 10(1). 
Kobia, M., \&Bagaka, O. (2014). Separation of powers in Kenya’s devolved administrative system: Opportunities and challenges. Commonwealth Governance Handbook.

Kosec, K., \&Mogues, T. (2015). The Impact of Decentralization on Public Service Delivery: A Spatial Regression Discontinuity Approach. International Food Policy Research Institute.

Kothari, C. R. (2004). Research Methodology : Methods and Techniques. Mumbai: New Age International (P) Ltd.

Kothari, C. R., \&Garg, G. (2014). Research Methodology : Methods and Techniques. Mumbai: New Age International (P) Ltd.

Krishnan, S., \&Teo, T. S. H. (2012). Moderating Effects of Governance on Information Infrastructure and E-Government Development. Journal Of The American Society For Information Science And Technology, 63(10), 1929_ 1946.

Mason, R. D., Lind, D. A., \&Marchal, W. G. (1999). Sttistical Techiques in Business and $\mathrm{E}$ conomics.

Mitchell, A., \&Bossert, T. J. (2010). Decentralisation, Governance and Health- System Performance: 'Where You Stand Depends on Where You Sit’. Development Policy Review, 28(6), 669-691.

Mobarak, A., Rajkumar, A., \&Cropper, M. (2006). The political economy of health service provision in Brazil WP S3508- University of Colorado, Boulder.

Monga, A. (2008). E-government in India: Opportunities and challenges. Journal of Administration and Governance, 3(2), 52-61.

Mongkol, K. (2011). The Critical Review of New Public Management Model and its Criticisms. Research Journal of Business Management, 5(1), 35-43.

Mugenda, O. M., \&Mugenda, A. G. (2003). Research Methods: Quantitative \& Qualitative Approaches. Nairobi: African Centre for Technology Studies Press.

Naz, R. (2009). E-Governance for Improved Public Service Delivery in Fiji. Journal of Service Science \& Management, 3, 190-203.

Olatona, J. B., \&Olomola, P. A. (2015). Analysis of Fiscal Decentralization and Public Service Delivery in Nigeria. Journal of Economics and Sustainable Development, 6(9).

Osborne, D., \&Gaebler, T. (1992). Reinventing government: How the entrepreneurial spirit is transforming the public sector. . New York: Penguin Books.

Ozmen, A. (2014). Notes to the concept of decentralization. European Scientific Journal, 10(10).

Pallant, J. F. (2011). SPSS Survival Manual: A step by step guide to data analysis using SPSS (4th ed.). . Crows Nest, NSW: Allen \& Unwin. 
Pan, C.-H., \&Jang, C.-L. (2008). The Institutional Effects on the Evolvement of e-Government Online Service Delivery in the U.S. Cities. Public Administration \& Policy, 47, 131-176.

Resnick, D. (2014). Urban Governance and Service Delivery in African Cities: The Role of Politics and Policies. Development Policy Review(32), 1.

Saavedra, P. A. (2010). A Study of the Impact of Decentralization on Access to Service Delivery. (Doctor in Philosophy in the Andrew Young School of Policy Studies and the School of Public Policy), Georgia State University.

Sekaran, U. (2006). Research Methods for Business (fourth Ed.). Hoboken, NJ:John Wiley \& Sons.

Simiyu, R. S., Mweru, J. N., \&Omete, F. I. (2014). The Effects of Devolved Funding On Socio- Economic Welfare of Kenyans: A Case of Constituency Development Fund In Kimilili, (Kenya). European Journal of Accounting Auditing and Finance Research, 2(7), 31-51.

Simonet, D. (2008). The New Public Management theory and European health-care reforms. The Institute of Public Administration of Canada, 51(4), 617-635.

Singh, G., Pathak, R. D., \&Naz, R. (2010). Service delivery through egovernance:Perception and expectation of customers in Fiji and PNG.

. Public Organization Review: A Global Journal.

Smoke, P. (2015). Rethinking Decentralization: Assessing Challenges to A Popular Public Sector Reform. Public Administration and Development(35), 97-112.

Srivastava, S. C. (2011). Is e-government providing the promised returns?A value framework for assessing e-government impact. Transforming Government: People, Process and Policy,, 5(2), 107-113.

Stanton, A. (2009). Decentralisation and Municipalities in South Africa: An Analysis of The Mandate to Deliver Basic Services. (Degree of Doctor of Philosophy (Policy and Development Studies)), University of KwaZuluNatal, Pietermaritzburg.

Tolofari, S. (2005). New Public Management and Education Policy Futures in Education, 3(1).

Tshukudu, T. T. (2014). Decentralization as a Strategy for improving Service delivery in the Botswana Public Service Sector. Journal of Public Administration and Governance, 4(2).

Zungura, M. (2014). Understanding New Public Management within the Context of Zimbabwe International Review of Social Sciences and Humanities, 6(2), 246-253. 